\title{
PENINGKATAN KEMAMPUAN BERPIKIR LOGIS MELALUI PENERAPAN DISCOVERY LEARNING PADA MATERI SISTEM REPRODUKSIDI KELAS XI MIA 1 SMA BATIK 2 SURAKARTA TAHUN PELAJARAN 2014/2015
}

\author{
IMPROVE THE STUDENTS' LOGICAL THINKING THROUGH DISCOVERY \\ LEARNING APLICATION ABOUT REPRODUCTION SYSTEM MATERIAL IN XI \\ MIA 1 OF SMA BATIK 2 SURAKARTA ACADEMIC YEAR 2014/2015
}

\author{
SONDRA SWESTYANI, YUDI RINANTO, SRI WIDORETNO \\ Program Studi Pendidikan Biologi \\ Fakultas Keguruan dan Ilmu Pendidikan \\ Universitas Sebelas Maret \\ J1. Ir. Sutami 36 A, Surakarta, 57126, Indonesia \\ *Corresponding Author: swestyani@yahoo.co.id
}

Manuscript received : 11 Januari 2016 Revision accepted: 22 Maret 2016

\begin{abstract}
This research was aimed to improve the students' logical thinking in XI MIA 1 of SMA Batik 2 Surakarta Academic Year 2014/2015 about reproduction system material through discovery learning application.This research was a class action research which consisted of three cycles. Each cycle contains planning, implementing, observing and reflecting. The research subject was the students in XI MIA 1 of SMA Batik 2 Surakarta Academic Year 2014/2015. The data source was from the mind map that cover the logical thinking aspects. Data collecting techniques of this research used observation, interview and documentation then data validation was using triangulation method. Data analyzing technique of this research was descriptive qualitative analysis which was done in three components, they are: data reduction, data presentation and drawing the conclusion or verification. The research' procedure used spiral mode which is interdependent. The result of the research showed that the implementation of discovery learning improves the students' logical thinking that covers aspects of knowledge, comunication, thinking, and application. The persentage of knowledge aspect was 53,23\% in pre cycle, $81,04 \%$ in first cycle , 89,11\%, in second cycle, and $95,16 \%$ in third cycle . The persentage of comunication aspect was $28,33 \%$ in pre cycle, $35,08 \%$ in first cycle, $67,74 \%$ in second cycle, and $71,77 \%$ in third cycle. The persentage of thinking aspect was $28,33 \%$ in pre cycle, $58,87 \%$ in first cycle, $49,19 \%$ in second cycle, and $73,39 \%$ in third cycle. Then the persentage of knowledge aspect was $41,53 \%$ in pre cycle, $72,18 \%$ in first cycle, $79,03 \%$ in second cycle, and 77,42\% in third cycle. This research's conclusion was the implementation of discovery learning can improve the students' logical thinking in X MIA 1 of SMA Batik 2 Surakarta academic Year 2014/2015 about reproduction system material.
\end{abstract}

Keywords :discovery learning, logical thinking

\section{PENDAHULUAN}

Pendidikan di abad 21 diperlukan untuk melatih keterampilan memecahkan masalah dan kemampuan berpikir peserta didik. Kemampuan berpikir yang mendukung pemecahan masalah salah satunya yaitu kemampuan berpikir logis. Berpikir logis merupakan cara berpikir yang runtut, masuk akal, dan berdasarkan fakta-fakta objektif tertentu (Hadi, 2004). Kesesuian antara fakta objektif yang diperoleh dari kajian literatur dengan topik yang dipelajari menunjukkan adanya jalan pemikiran yang logis (Fios, 2013). Jalan pemikiran logis terlihat dari hierarki, yaitu sebuah sistem yang mengatur informasi-informasi dalam sebuah kelas, dimulai dari hal paling umum menjadi hal spesifik (Matlin, 2009). Hierarki dituangkan dalam bentuk garis, lambang, kata-kata dan gambar yang terangkum dalam mind map (Suriaty, Asyril, \& Mulyani, 2007).

Mind map merupakan pendekatan keseluruhan otak yang mampu membuat catatan secara menyeluruh dalam satu halaman dengan menggunakan citra visual dan perangkat grafis. Mind map sebagai metode mencatat efektif digunakan untuk melihat profil kemampuan berpikir logis peserta didik (Tony buzan, 2007). Mind map memiliki empat aspek yaitu aspek pengetahuan, komunikasi, berpikir, dan aplikasi (Ohassta, 2004).

Pemecahan masalah menggunakan cara berpikir logis membutuhkan kemampuan untuk mengerti fakta dan memahami konsep yang dipelajari dalam proses pembelajaran (Yaman, 2005).

Proses pembelajaran yang telah diobservasi menunjukkan bahwa peserta didik di kelas XI MIA 1 
SMA Batik 2 Surakarata yaitu sebanyak 31 peserta didik meliputi aspek pengetahuan (55\%), aspek komunikasi $(28,33 \%)$, aspek berpikir $(28,33 \%)$, dan aspek aplikasi $(42,92 \%)$. Analisis mengenai mind map peserta didik menunjukkan bahwa kemampuan berpikir logis peserta didik masih rendah, sehingga perlu adanya peningkatan kemampuan berpikir logis melalui proses pembelajaran.

Proses pembelajaran yang diharapkan meningkatkan kemampuan berpikir logis peserta didik adalah pembelajaran yang mampu melatih peserta didik untuk menemukan konsep pengetahuan secara mandiri. Penemuan konsep pengetahuan secara mandiri ditingkatkan melalui kegiatan penyelidikan. Kegiatan penyelidikan ditemukan dalam pembelajaran dengan menggunakan model Discovery Learning (Fios, 2013).

Discovery Learning mengacu pada penguasaan pengetahuan untuk dirinya sendiri yang terlaksana apabila peserta didik tidak diberikan informasi atau pemahaman konsep secara langsung oleh guru melainkan harus menemukan informasi dan konsep melalui referensi yang tersedia, sehingga pemikiran peserta didik disiapkan untuk belajar menemukan (Alfieri, Patricia, \& Naomi, 2011). Discovery Learning memiliki lima sintaks yaitu orientation, hypothesis generation, hypothesis testing, conclusion, dan regulation (Veermans, 2002). Orientation adalah saat dimana peserta didik membangun pemahamna awal dengan melibatkan informasi dan pengetahuan yang telah didapat sebelumnya. Hypothesis generation adalah saat peserta didik menyusun hipotesis. Hypothesis testing adalah saat peserta didik merencanakan dan melakukan percobaan untuk menguji hipotesis. Conclusion adalah saat peserta didik mereview hasil percobaan dan mengaitkannya dengan hipotesis yang telah dibuat. Regulation adalah saat peserta didik bersama guru mereview hasil pekerjaan.

\section{METODE PENELITIAN}

Penelitian ini adalah Penelitian Tindakan Kelas (PTK) yang bertujuan untuk untuk meningkatkan kemampuan berpikir logis melalui penerapan discovery learning pada materi sistem reproduksi di Kelas XI MIA 1 SMA Batik 2 Surakarta Tahun Pelajaran 2014/2015.

Prosedur penelitian mengikuti model yang dikembangkan oleh Kemmis dan Robin MC Taggart dalam dalam Arikunto, Suhardjono, dan Supardi (2008) yang berupa model spiral yaitu dalam satu siklus terdiri dari tahap perencanaan, tindakan, observasi dan refleksi. Pelaksanaan tindakan siklus dilaksanakan setelah observasi pra-siklus.
Penerapan tindakan berupa discovery learning dilaksanakan dalam tiga siklus yaitu siklus I, siklus II, dan siklus III. Siklus I direncanakan dan dilaksanakan berdasarkan hasil analisis observasi prasiklus, siklus II direncanakan dan dilaksanakan berdasarkan refleksi siklus I, dan siklus III direncanakan dan dilaksanakan berdasarkan refleksi siklus II sehingga penerapan discovery learning meningkatkan kemampuan berpikir logis secara signifikan.

\section{HASIL DAN PEMBAHASAN}

Hasil penelitian mengenai kemampuan berpikir logis ditinjau dari hasil mind map. Kemampuan berpikir logis dari pra-siklus, siklus I, siklus II, dan siklus III disajikan pada Gambar 1.

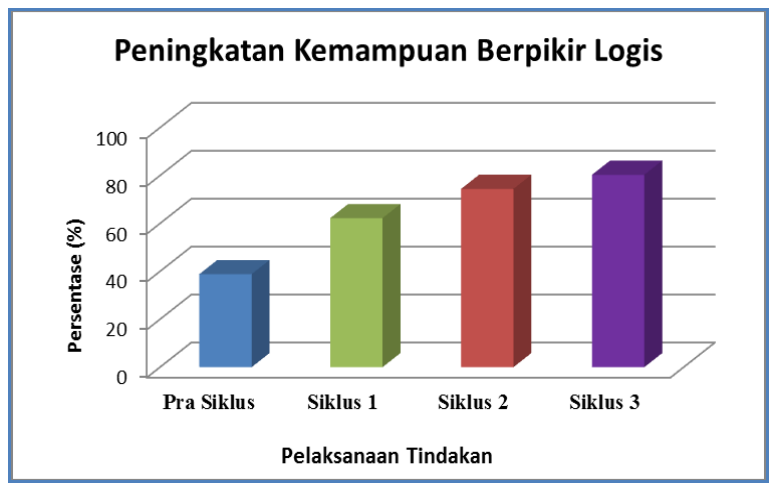

Gambar 1. Diagram Peningkatan Kemampuan Berpikir Logis Tiap Siklus

Berdasarkan diagram Gambar 1 diketahui bahwa kemampuan berpikir logis mengalami peningkatan pada setiap siklus. . Persentase kemampuan berpikir logis mengalami peningkatan yang signifikan dari pra siklus hingga Siklus I yaitu dari $38,82 \%$ menjadi $62,21 \%$. Persentase kemampuan berpikir logis dari Siklus I ke Siklus II mengalami peningkatan dari $62,21 \%$ menjadi $74,42 \%$. Persentase kemampuan berpikir logis dari Siklus II ke Siklus III mengalami peningkatan dari 74,42\% menjadi $80,30 \%$.

- Kemampuan berpikir logis peserta didik mengalami peningkatan selama dilakukan tindakan penerapan discovery learning menunjukkan bahwa discovery learning memberi dampak positif bagi proses pembelajaran untuk meningkatkan kemampuan berpikir logis. Penerapan discovery learning menciptakan suasana belajar yang bermakna dan menjadikan peserta didik aktif dan mandiri dalam menemukan jawaban atas permasalahan yang dirumuskan oleh peserta didik sendiri. Keaktifan dan kemandirian peserta didik dalam menemukan jawaban atas permasalahan mampu memperbanyak informasi belajar peserta didik sehingga meningkatkan 
pemahaman konsep. Kesesuaian antara pemahaman konsep dan materi yang dipelajari menunjukkan kemampuan berpikir logis peserta didik yang baik. Proses penemuan (discovery learning) merupakan bagian dari siklus penyelidikan (inquiry) (Saab, Joolingen, \& Hout-Wolters, 2005).

Partisipasi dalam kegiatan penyelidikan mendorong peserta didik untuk menghasilkan kesimpulan berdasarkan fakta objektif, membangun argumen, mengkomunikasikan temuan hasil penyelidikan, dan menggunakan pilihan mengenai strategi penalaran yang melibatkan kritis, kreatif, kausal, dan berpikir logis (Olson \& Loucks-Horsley, 2000; Minstrell \& van Zee dalam Chin \& Chia, 2006).

Peningkatan kemampuan berpikir logis selama proses pembelajaran dilandasi oleh kualitas mind map yang dibuat oleh peserta didik. Mind map digunakan sebagai alat ukur untuk melihat profil kemampuan berpikir logis karena mind map merupakan catatan yang berisi keruntutan berpikir dan informasi belajar peserta didik.

Informasi belajar peserta didik meliputi kedalaman isi materi yang dipelajari selama pembelajaran dan penjabaran isi materi. Informasi belajar peserta didik dapat dilihat dari aspek pengetahuan dan aplikasi. Keruntutan berpikir peserta didik meliputi keruntutan berpikir dari hal yang umum ke hal yang khusus dan visualisasi materi dalam bentuk simbol serta kata kunci. Keruntutan berpikir peserta didik dapat dilihat dari aspek komunikasi dan berpikir.

Aspek pengetahuan meliputi kedalaman isi materi. Capaian persentase aspek pengetahuan dari pra siklus hingga Siklus III mengalami peningkatan. Peningkatan aspek pengetahuan dari pra siklus hingga Siklus III dilihat pada Gambar 2.

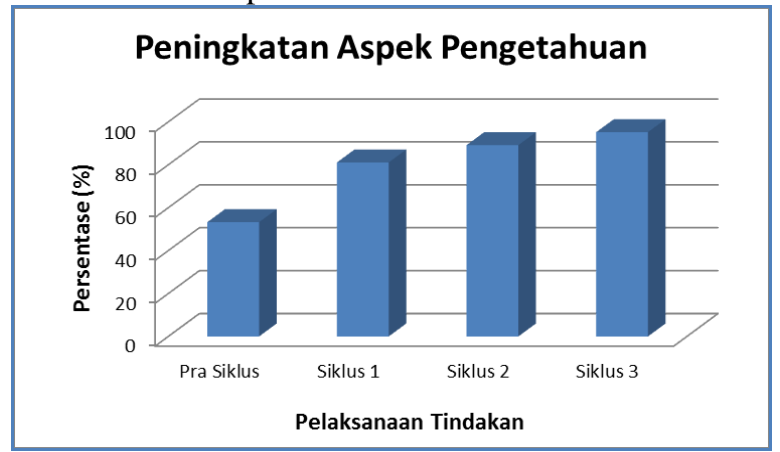

Gambar 2. Diagram Peningkatan Aspek Pengetahuan

Peningkatan aspek pengetahuan dipengaruhi oleh kontribusi tahap orientation dan hypothesis testing. Penyajian fenomena pada tahap orientation berupa fakta yang berfungsi untuk menuntun peserta didik mengingat informasi yang disajikan sebelumnya (Gall, 1984) dan mengenalkan informasi baru sehingga meningkatkan pemahaman terhadap konsep materi
(Cotton , 1998). Kegiatan mengamati, mengumpulkan data, dan menganalisis pada tahap hypothesis testing mengakomodasi peserta didik untuk mendorong peserta didik mengartikulasikan ide-ide, pemahaman, pengalaman dan pendapat pribadi (Oliveira (2009).

Capaian aspek pengetahuan mempengaruhi capaian aspek aplikasi. Hal ini dikarenakan kedua aspek tersebut meliputi pemahaman konsep peserta didik berupa kedalaman isi materi dan penjabaran konsep materi. Peningkatan aspek aplikasi dari pra siklus hingga Siklus III dilihat pada Gambar 3.

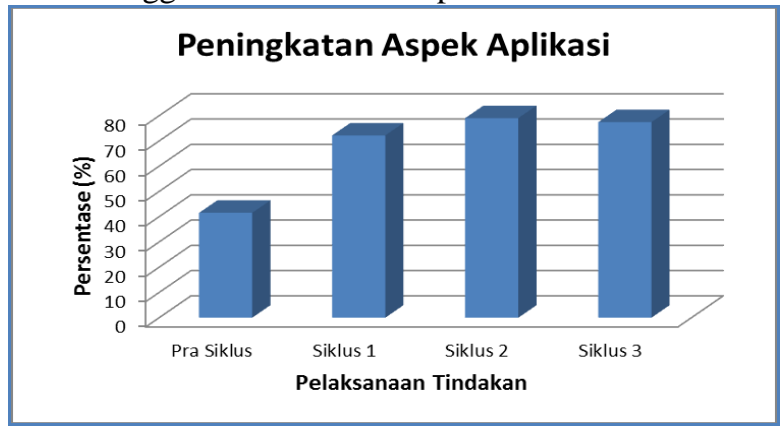

Gambar 3. Diagram Peningkatan Aspek Aplikasi

Penurunan aspek komunikasi pada Siklus III disebabkan kurang maksimalnya pelaksanaan tahap hypothesis testing. Hypothesis testing terdiri dari kegiatan mengamati, mengumpulkan data, dan menganalisis data dengan tujuan membuktikan hipotesis dan menemukan jawaban dari masalah yang telah dirumuskan (Veermans, 2003). Data yang dikumpulkan selanjutnya didiskusikan oleh peserta didik untuk di analisis (Scott, Tomasek \& Matthews, 2010). Terbatasnya sumber belajar menyebabkan peserta didik kurang maksimal dalam mengumpulkan data sehingga informasi yang didapat tidak maksimal.

Aspek komunikasi meliputi visualisasi informasi yang didapatkan peserta didik saat pembelajaran ke dalam simbol. Capaian persentase aspek komunikasi dari pra siklus hingga Siklus III mengalami peningkatan. Peningkatan aspek pengetahuan dari pra siklus hingga Siklus III dilihat pada Gambar 4.

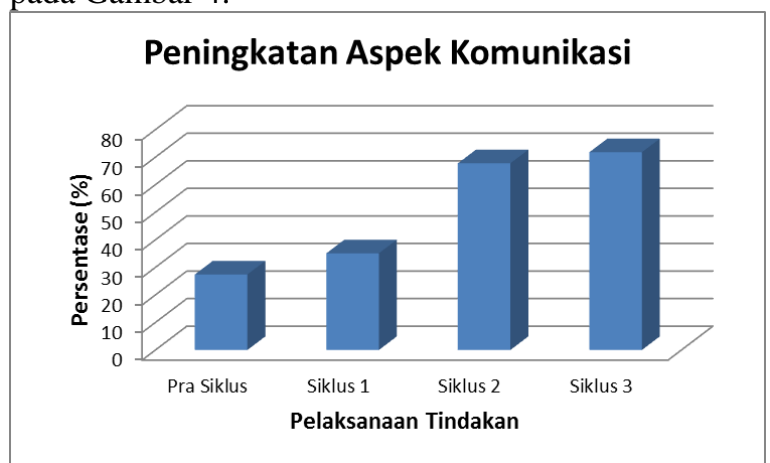

Gambar 4. Diagram Peningkatan Aspek Komunikasi 
Peningkatan aspek komunikasi pada Siklus III dipengaruhi oleh kontribusi tahap hypothesis testing dan conclusion dalam discovery learning. Hypothesis testing memberikan pengalaman dalam membentuk prediksi berdasarkan bukti kepada peserta didik, membantu peserta didik dalam berpikir sebab-akibat dan mengarahkan peserta didik dalam pembelajaran (Walsh and Sattes, 2011). Penyelidikan berfungsi untuk membantu peserta didik dalam memperluas pengetahuan, membangun proses berpikir peserta didik, pemahaman dan pengetahuan sehingga membantu peserta didik untuk memvisualisasikan ke dalam simbol tentang pengetahuan yang didapatkan. Conclusion merupakan kegiatan menarik kesimpulan berdasarkan kegiatan mengamati, mengumpulkan data, dan analisis.

Capaian aspek komunikasi mempengaruhi capaian aspek berpikir. Hal ini dikarenakan kedua aspek tersebut meliputi visualisasi pengetahuan ke dalam simbol dan kata kunci yang mewakili komponen materi serta hubungan antar kata. Peningkatan aspek berpikir dari pra siklus hingga Siklus III dilihat pada Gambar 5.

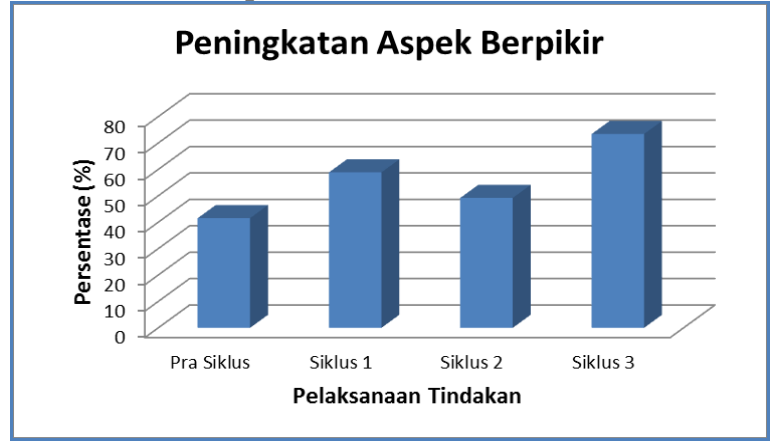

Gambar 5. Diagram Peningkatan Aspek Berpikir

Penurunan persentase Siklus I ke Siklus II sebesar $9,68 \%$, sedangkan peningkatan persentase dari Siklus II ke Siklus III sebesar $24,20 \%$. Penurunan persentase aspek berpikir dari Siklus II ke Siklus III disebabkan karena kurang maksimalnya pelaksanaan tahap hypothesis testing dan conclusion. Conclusion menurut Walsh and Sattes (2011) berfungsi mendorong peserta didik untuk menemukan petunjuk atau bukti, hasil analisis, dan membuat penentuan mengenai kemungkinan hasil kesimpulan yang bermanfaat untuk menghubungkan antar komponen materi pembelajaran.

Hasil wawancara peserta didik mengenai mind map menunjukkan bahwa peserta didik sangat terbantu untuk memahami konsep pembelajaran ketika menggunakan discovery learning dan metode mencatat mind map. Peserta didik lebih mudah mengingat informasi dan mengaitkan konsep dengan menggunakan metode mind map. Pembelajaran menjadi lebih menyenangkan dan memacu rasa ingin tahu ketika menggunakan discovery learning dibanding menggunakan ceramah.

Hasil wawancara dengan guru menunjukkan bahwa penerapan discovery learning menjadikan peserta didik lebih aktif mencari tahu informasi belajar dengan berdiskusi dan bertanya kepada teman maupun guru sehingga pemahaman konsep materi menjadi lebih baik, peserta didik berpartisipasi aktif dalam kegiatan penyelidikan, guru menjadi lebih fokus saat mengaajar, dan kelas menjadi lebih kondusif.

Discovery learning merupakan pembelajaran menggunakan pendekatan scientific (Klahr \& Nigam, 2004) yang berpotensi meningkatkan kinerja peserta didik selama proses pembelajaran (Akanmu \& Fajemidagba, 2013). Discovery learning menurut Zhang, Chen, and Reid (2000) dianggap sebagai proses penalaran ilmiah yang melibatkan kegiatan menyusun hipotesis dan menguji hipotesis melalui bukti yang dikumpulkan. Discovery learning merupakan pembelajaran konstruktivis yang melibatkan kegiatan pengaktifan pengetahuan sebelumnya, interpretasi masalah, penjelasan dari hasil percobaan, dan modifikasi serta integrasi pemahaman konsep.

Berdasarkan hasil pembahasan diketahui bahwa penerapan dyscovery learning dapat meningkatkan kemampuan berpikir logis peserta didik kelas XI MIA 1 SMA Batik 2 Surakarta.

\section{SIMPULAN}

Kesimpulan penelitian adalah penerapan discovery learning meningkatkan kemampuan berpikir logis pada materi sistem reproduksi di kelas XI MIA 1 SMA Batik 2 Surakarta Tahun Pelajaran 2014/2015.

\section{DAFTAR PUSTAKA}

Akanmu, M. A., \& Fajemidagba, M. O. (2013). Guided Discovery Learning Strategy and Senior School Students Performance in Mathematic in Ejigbo, Nigeria. Journal of Education and Practice , IV (12), 82-89.

Alfieri, Patricia, \& Naomi. (2011). Does Discovery Based Instruction Enhance Learning. Journal of Education Psychological, 103(1), 1-18

Arikunto, S., Suhardjono, \& Supardi. (2008). Penelitian Tindakan Kelas. Jakarta: PT Bumi Aksara.

Buzan, Tony. (2007). Buku Pintar Mind Map. PT Gramedia Pustaka Utama, Jakarta

Chin, C., \& Chia, L.-G. (2006). Problem-Based Learning: Using II-Structured Problem in Biology Project Work. Science Education , XC (1), 44-67.

Chin, C., \& Osborne, J. (2008). Students' Question: a Potential Resource for Teaching and Learning 
Science. Studies in Science Education, XLIV (1), 139.

Fios, frederikus. (2013). Pengantar filsafat: ilmu dan logika. Jakarta: Salemba Humanika

Hadi, Sutrisno. (2004). Metodologi Research Jilid 3. Yogyakarta: Andi.

Klahr, D., \& Nigam, M. (2004). The Equivalence of Learning Paths in Early Science Instruction: Effects of Direct Instruction and discovery Learning. Psycological Science , XV (10), 661-667.

Matlin, M. E. (2009). Cognitive Psychology. Seventh Edition. Internasional Student Version. Jhon Wiley $\&$ Sons, Inc.

Ohassta. (2004). Mind Mapping Rubric Ontario history and social sciences teachers' association

Oliveira, A. W. (2010). Improving Teacher Questioning in Science Inquiry Discussions Through Professional Development. Journal of Research in Science Teaching , XLVII (4), 422-453.

Saab, N., van Joolingen, W. R., \& van Hout-Wolters, B. H. (2005). Communication in Collaborative Discovery Learning. British Journal of Education Psicology, LXXV (4), 603-621.

Schunk, D.H., (2012). Teori-Teori Pembelajaran: Persepektif Pendidikan. Yogyakarta: Pustaka Belajar.

Scott, C., Tomasek, T., \& Matthews, C. E. (2010). Thinking like a Ssssscientist! Fear of Snakes Inspires a Unit on Science as Inquiry. Science \& Children, XLVIII (1), $38-42$.

Suriaty, Asyril, dan Mulyani. (2007). Pengaruh Penggunaan Peta Pikiran Terhadap Hasil Belajar Matematika Siswa Pada Pokok Bahasan Bilangan Bulat Di Kelas VII Semester 1 SMPN 11 Samarinda. Jurnal Didaktika. 8. (2): 156-162 hlm.

Veermans, K. (2002). Intelligent Support for Discovery Learning. Ph.D. Thesis University of Twente: Twente University Press

Walsh, J. A., \& Sattes, B. D. (2011). Thinking Through Quality Questioning: Deepening Student Engagement. United States of America.

Yaman, Suleyman. (2005). Effectiveness on development of logical thinking skills of problem based learning skills in science teaching. Journal of Turkish Science Education, 2(1), 31-33.

Zhang, Z., Chen, Q., \& Reid, D. J. (2000). Simulation-Based Scientific Discovery Learning: a Research on The Effects of Experimental Support and Learners' Reasoning Ability. Proceedings of Conference on Educational Use of Information and Communication Technology, 344-351. 